\title{
Post-Maastricht Blues: The Transformation of Citizen Support for European Integration, 1973-2004
}

\author{
Richard C. Eichenberg ${ }^{\mathrm{a}}$ and Russell J. Dalton ${ }^{\mathrm{b}}$ \\ ${ }^{a}$ Department of Political Science, Tufts University, Eaton Hall, 3rd Floor, Medford, MA 02155, \\ USA. \\ E-mail: Richard.eichenberg@tufts.edu \\ ${ }^{\mathrm{b}}$ Department of Politics and Society, University of California, Irvine, CA 92697 USA. \\ E-mail: Rdalton@uci.edu
}

Macroeconomic forces have influenced aggregate citizen support for European integration in the past, but no study analyzes historical data beyond the early 1990s. This gap is lamentable, because public support for integration has moved in precisely the opposite direction that past research would predict. We analyze data on support for the EU during the period 1973-2004 for eight long-term member states. Four conclusions emerge from the analysis. First, there has been considerable cross-national convergence in citizen support for integration. Second, although economic factors influence citizen support over the entire 1973-2004 period, these impacts are much weaker than reported in past research. Third, the effect of inflation and trade concentration essentially disappeared in the aftermath of the Maastricht Treaty. Fourth, citizen support for integration of specific policy areas, such as foreign policy, social security, and monetary policy, suggests that the precipitous decline in support that began in 1991 was a reaction to Economic and Monetary Union (EMU) and its budgetary implications. We argue that the politics of European integration are now animated by distributive concerns as well as by evaluations of absolute economic performance. This argument has important implications for the study of European integration.

Acta Politica (2007) 42, 128-152. doi:10.1057/palgrave.ap.5500182

Keywords: public opinion; European integration; European Union; political economy

\section{Introduction}

After the signing of the Single European Act (SEA) in 1985, the Eurobarometer surveys indicated that citizen enthusiasm for European integration grew to historically unprecedented levels (Eichenberg and Dalton, 1993). ${ }^{1}$ By 1991 it reached a zenith in popular support for the European Union. 


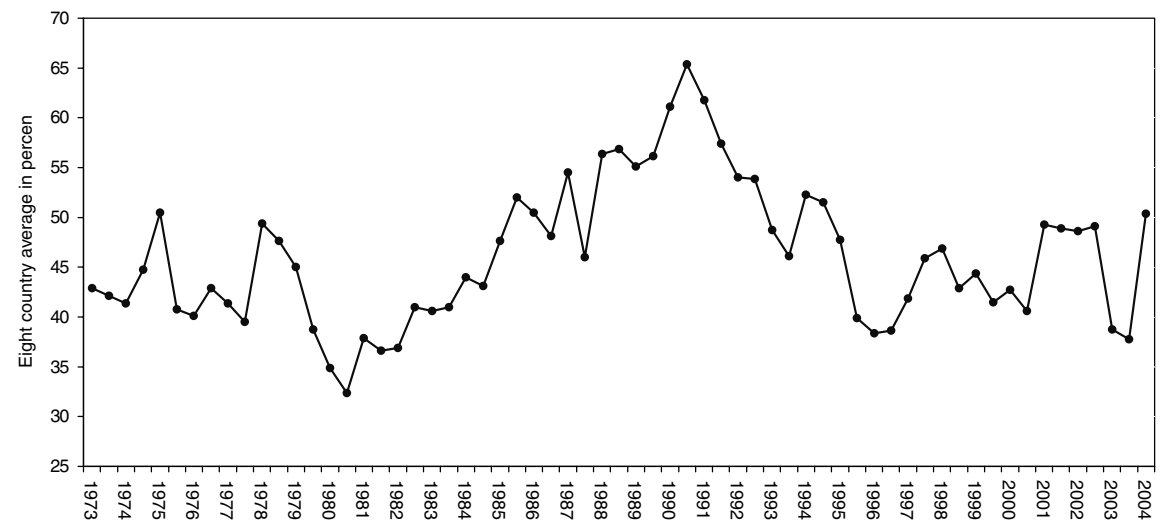

Figure 1 Evolution of net support for European integration, 1973-2004. Source: Eurobarometer surveys. Note: The figure presents Net Support, which is the percent responding 'good thing' minus the percent responding 'bad thing', averaged over the eight countries under study.

However, as others in this volume have noted, public support for the European project began to erode following the Maastricht agreement (see Figure 1).

Given the ambitious reform agenda laid out in the Maastricht Treaty, perhaps it is not surprising that Europe's leaders reacted to public alienation in the mid-1990s by articulating a commitment to respect citizen opinion: '...citizens are at the core of the European construction: the Union has the imperative to respond concretely to their needs and concerns'. (European Council, 1996, 1). This articles focuses on what factors determine the concerns of Europeans about the EU. We review existing studies of public opinion and European integration and highlight the consistent finding that macroeconomic performance and trade integration are strongly related to citizen support for integration.

However, most existing research on these economic factors extends only to the late 1980s or the early 1990s. Little published time series research includes the important post-Maastricht period. The paucity of recent research is a crucial gap in the literature, because the trends in public opinion after the Maastricht Treaty runs directly counter to the predictions of earlier research. Previous research suggests that macroeconomic performance had a strong positive influence on support for the EU up to 1990. However, public opinion then tracked dramatically downward despite the generally positive economic conditions of the 1990s. Recent experience therefore seems to undermine what we thought we knew about the determinants of domestic support for integration. This article explains this apparent anomaly by demonstrating that European citizens are increasingly more concerned about the distributive effects of integration than by aggregate economic performance. 


\section{Past Research on Citizen Support for European Integration}

The explosion of academic and political interest that accompanied the relaunching of Europe in the mid-1980s stimulated several attempts to model the determinants of citizen support for European integration. A primary theoretical inspiration was utilitarian theories of EU support. In this framework, largely deduced from liberal trade and neofunctionalist theories, citizens evaluate the integration process in terms of costs and benefits. For instance, citizens will support integration to the extent that policy outcomes such as trade liberalization - actually result in the welfare gains predicted both in theory and in the promises of politicians. ${ }^{2}$

Several studies asked whether citizens evaluated the EU based on macroeconomic performance, including growth, unemployment, and inflation (Eichenberg and Dalton, 1993; Anderson and Reichert, 1995; Gabel and Palmer, 1995). There was much to suggest that they should. Historically, the European Union had been primarily an economic enterprise, justified by its founders in terms of the welfare gains from trade and by subsequent reformers in terms of its role in producing price stability (the European Monetary System - EMS - and its successors). Of course, political elites justified the establishment and consolidation of the customs union precisely on the grounds that it would increase standards of living, and beginning in the mid-1970s elites made similar claims on behalf of monetary policy coordination. For example, Moravcsik states: 'French support for the EMS over the next few years was aimed primarily at providing external support for Giscard and Barre's domestic economic plan. The EMS provided an anti-inflationary anchor...' $(1998,266)^{3}$

In addition, research found that intra-European trade concentration and macroeconomic conditions significantly influenced aggregate public support for integration. In one of the first studies on the subject, Eichenberg and Dalton (1993) analyzed the period 1973-1988 and found that the level and growth of intra-European exports was a very significant and positive correlate of support for European integration. These early findings were confirmed in a number of subsequent studies (Anderson and Reichert, 1995; Gabel and Palmer, 1995; Gabel and Whitten, 1997; Gabel, 1998a). This body of research displays an impressive consistency of findings across a variety of country samples, time periods, levels of aggregation, measurement strategies, and estimation techniques. Intra-European trade concentration consistently emerged as a strong, positive predictor of aggregate support for integration. In addition, research confirmed the importance of economic conditions including inflation, unemployment, and growth - as well as the importance of perceptions of economic conditions (Anderson and Kaltenthaler, 1996; Bednar et al., 1996; Gabel and Whitten, 1997). 
The most impressive confirmation of the importance of economic calculations is the work of Gabel, who directly models the individual gains from trade liberalization (Gabel and Whitten, 1997; Gabel, 1998a, b). Gabel measures the relative competitiveness of individuals based on their occupation, education, and income relative to others across Europe. He demonstrated that variables representing the personal potential to gain from trade were among the strongest correlates of individual-level support for integration, a dramatic illustration of the sophistication of individual citizens. That sophistication is further reflected in studies that show that citizens respond to the EU's policy direction, to the distribution of benefits through the EU budget, and to the apparent gender distribution of social benefits (Whitten et al., 1996; Franklin and Wlezien, 1997; Nelson and Guth, 2000; Netjes, 2004). There is also evidence that citizens evaluate Economic and Monetary Union (EMU) according to its likely impact on personal standards of living (Gabel, 1994). ${ }^{4}$

These findings imply that European political leaders could hope to build consensus for further integration by producing policy outcomes that garner support - especially by maintaining price stability and by promoting growth through expanded intra-European trade. Indeed, drawing on our own research findings, we argued some time ago that if the implementation of the SEA and Maastricht treaty proceeds successfully, in the long run it should reinforce the support for the community that evolved in the 1980s... intra-EC trade has had a profound positive impact on EC support. With the implementation of the SEA, intra-EC trade should accelerate. Furthermore, to the extent that the internal market contributes to growth in general and monetary union to anti-inflationary growth in particular, citizen support is further enhanced' (1993, 531).

This conclusion proved premature, for it directly clashes with post-Maastricht trends in European attitudes towards the EU. Public support for European integration dropped in the $1990 \mathrm{~s}$ at a rate that is unprecedented in the history of the Eurobarometer surveys (see Figure 1). This occurred during a period in which intra-European trade was expanding as a result of the SEA and during which economic conditions - the inflation rate in particular — were generally favorable. ${ }^{5}$ However, most published studies of macroeconomic factors end with data from the early 1990s. One important exception argues that support for integration during the 1990s was a function of both economic performance and attachment to national identity, but the study does not compare these relationships with similar data from the 1970s and 1980s (Netjes, 2004). Similarly, Hooghe and Marks $(2004,2005)$ show convincingly in several studies that national identity can supplant or complement economic considerations in determining support for Europe, but the empirical analysis is confined to crosssectional analysis of a single survey at one point in time. Thus, analysis of public opinion that includes both compete historical data and the post-Maastricht period may reveal a weakening or reversal of previous relationships. 
This is not merely a technical argument based on the coverage of data samples. Rather, one could argue that the Maastricht Treaty was truly a 'system transforming' event that dramatically altered the nature of the integration process and changed the public's cost/benefit calculations. Until Maastricht, the European Union was largely an economic entity. Thereafter, the Union moved in the direction of political integration by expanding the number of policy areas for which it has some responsibility; by expanding the coverage of majority voting in the Council; and by strengthening the powers of the European Parliament. The trend of accelerated integration continued in the Treaties of Amsterdam and Nice. The policy context of survey questions on integration has therefore changed over time. Survey respondents are not simply being asked if economic integration is a 'good thing'. They are also being asked to evaluate a Union that is more politically integrated and that now has powers in policy domains well beyond the economic.

What is more, the Post-Maastricht transition to EMU and particularly its convergence criteria may have even altered economic cost/benefit calculations. Before 1991 people could reasonably judge inflation as a negative, and since the EU sought to reduce inflation through the EMS, support for integration stood to gain from any success. As implementation of EMU began, however, the control of inflation became identified with its convergence sibling - the reduction of budget deficits - and the political fallout became apparent as taxes were raised and spending was restrained. Second, during the transition to EMU the European Central Bank (ECB) and the Commission began monitoring compliance with the deficit criteria and thus had an indirect impact on fiscal policy in the member states. In short, the Maastricht Treaty brought the EU into the arena of domestic redistribution by essentially enforcing a budgetary cap at a time of upward pressure on budgets brought on by demographic factors.

The drastic decline in support for the Union after Maastricht thus seems to confirm a prediction made by McNamara in her study of EMU: 'The analytical uncertainties and collective action problems of monetary politics are not nearly as prevalent in budget cutting, where the effects of pruning particular programs are immediately obvious to their constituencies, be they public workers, pensioners, or businesses. The "embedded liberalism" of the welfare state is thus likely to be more resilient than any other policy area in the face of increased pressures for reform, and popular opposition to EMU could accelerate...' (McNamara, 1998, 177).

\section{Data Collection and Model Specification}

This article re-evaluates past research findings by examining the stability of research results for EU support in the post-Maastricht period. We replicate 
previous work to reproduce research findings such that any change in the analyses can be traced to the extended time period of the study and not to methodological differences. We begin by specifying a model for the full 19732004 period that includes the same countries and the same set of variables that have been analyzed in the inherited literature. ${ }^{6}$

We measure Net Support for integration by subtracting the percentage of respondents who choose 'bad thing' from the percentage who choose 'good thing' in the following question from the bi-annual Eurobarometer surveys:

Generally speaking, do you think (your country's) membership in the Union is a good thing, a bad thing, or neither good nor bad?

In terms of face validity, this question seems to measure support for the EU. Membership in the European Union represents the existential fact of the integration process - endorsing membership is therefore endorsing the process of integration itself. In addition, the 'good thing' question is available for the longest time span; it is strongly related to economic and trade variables in past research; and it is most commonly used in the literature. There is much to suggest that the measure is a valid representation of support for integration. $^{7}$

The operationalization of the independent variables in the regression model is as follows: ${ }^{8}$

Macroeconomic conditions: We include the inflation rate (quarterly percentage change), an index of real GDP, and the (quarterly) unemployment rate.

$E U$ exports: We specify trade concentration as the percentage ratio of intraEU exports to total exports (intra-EU Export percentage).

Political factors: Dramatic political events surrounding the integration process can have a short-term (usually positive) effect on political support. For example, the signature of the SEA had a substantial positive upward effect on support for integration (Bednar et al., 1996). Others uncovered significant upward spurts for integration surrounding the membership referendum in the UK, the referendums on the SEA in Denmark and Ireland, and years in which there was an election to the European Parliament (Eichenberg and Dalton, 1993). The post-Maastricht referendums, German unification, the events of 11 September 2001, and the Iraq War are more recent events that might affect EU support. Therefore, in a preliminary model we estimated the impact of these events. Our multivariate models include only those event variables that proved statistically significant and thus merited inclusion.

National traditions: Virtually, all previous research demonstrates that country 'dummy' variables are significantly related to support for integration. We interpret these variables substantively as well as technically. Technically, specification of the variable is necessary to model uneven average levels in the dependent variable, which could bias parameter estimates in pooled 
cross-sectional time series models. Substantively, dummy variables represent the residue of historical foreign policy traditions. The UK, for example, has comparatively low levels of support for integration, resulting from centuries (not just decades) of ambivalence about European attachments. The Dutch, of course, reflect the opposite tradition - a small, commercially oriented state that has traditionally supported open trade and 'integration' through international law. The interesting question is whether, controlling for these national effects, there are additional factors that move opinion above or below its traditional baseline of support.

\section{Convergence in Support for European Integration}

Figure 1 begins our analysis by displaying the combined eight-nation trend in support for European Union over time. The early OPEC oil shocks of 1974 and 1981, and the economic dislocations they caused, had a negative effect on public support for European unification. But as the prior economic models imply, support grew as European economies strengthened during the late 1980s. By the first half of 1991 net support for European integration stood more than 20 percentage points above its average of 42 percent prior to the passage of the SEA. Yet even as European leaders finalized negotiations on the Maastricht Treaty in December 1991, popular support began to erode, and the decline continued precipitously through early 1997. By the spring of 1997 , average support for the integration process had dropped to 39 percent -below the average level that had prevailed prior to the SEA. Not surprisingly, therefore, ratification of the Maastricht Treaty proved difficult in many countries. Although support improved somewhat after 1997, it remained below the levels of the late 1980s and early 1990s, and in some countries it even remained lower than it had been in the 1970s and early 1980s. From the perspective of these figures, the failure of the constitutional referendums in the spring of 2005 seems less than surprising.

We developed a pooled cross-sectional model to explain these ebbs and flows in EU support across the eight nations. Table 1 contains the results of our baseline model for the entire 1973-2004 period. Several features of the results stand out. First, the overall explanatory power of this model is much less than in most previous studies. Although caution must be exercised in comparing $R^{2}$ statistics across different samples (King, 1986), the $R^{2}$ of 0.41 reported here is far short of the $R^{2}$ of 0.60 to 0.90 in earlier time series analyses (e.g., Eichenberg and Dalton, 1993; Gabel and Palmer, 1995; Anderson and Kaltenthaler, 1996, 175-199). This lower value of explained variance indicates that support for European integration has become harder to explain when post-Maastricht data are added. 
Table 1 Regression estimates of support for European integration, 1973-2004

\begin{tabular}{lcc}
\hline Dependent variable: level of net support $(N=504)$ & Parameter & Panel corrected standard error \\
\hline Constant & $43.352^{* * * *}$ & 12.003 \\
Macroeconomic performance & & \\
GDP & 0.643 & 7.877 \\
Inflation & $-1.217^{* * *}$ & 0.370 \\
Unemployment & -0.300 & 0.474 \\
& & \\
Export concentration & & \\
Intra-EU export \% & 0.137 & \\
& & \\
Political events & & 5.154 \\
UK membership referendum & $26.567^{* * *}$ & 5.457 \\
Danish SEA referendum & $20.547^{* * *}$ & \\
National traditions & & 4.942 \\
United Kingdom & $-37.898^{* * *}$ & 4.801 \\
Denmark & $-26.130^{* * *}$ & 6.979 \\
Ireland & 5.176 & 4.478 \\
Italy & $17.199^{* * *}$ & 4.028 \\
Netherlands & $19.285^{* * *}$ & \\
Controls & & 2.933 \\
German unification & $4.827^{* *}$ & \\
$R^{2}$ & 0.41 & \\
\hline
\end{tabular}

$* * * P<0.001 ; * P<0.10$.

Estimates follow the procedures described in Beck and Katz $(1995,1996)$ : ordinary-least squares estimates with panel-corrected standard errors and a nation-specific correction for serial autocorrelation.

Second, the regression parameters in Table 1 differ substantially from past findings. Export concentration, GDP, and unemployment - all prominent correlates in the literature - are not statistically significant. Only inflation is significantly related to support, and although its negative sign is consistent with both theory and existing evidence, its parameter is both less significant and less steep than is generally found in prior research. In short, with the exception of the continuing negative influence of inflation on support for Europe, the results depart substantially from findings that are prevalent in published research.

What has changed? One clue can be gleaned from the coefficients for national traditions. In most published research, these effects are large and significant. That is the case here as well, but with some important changes: the 


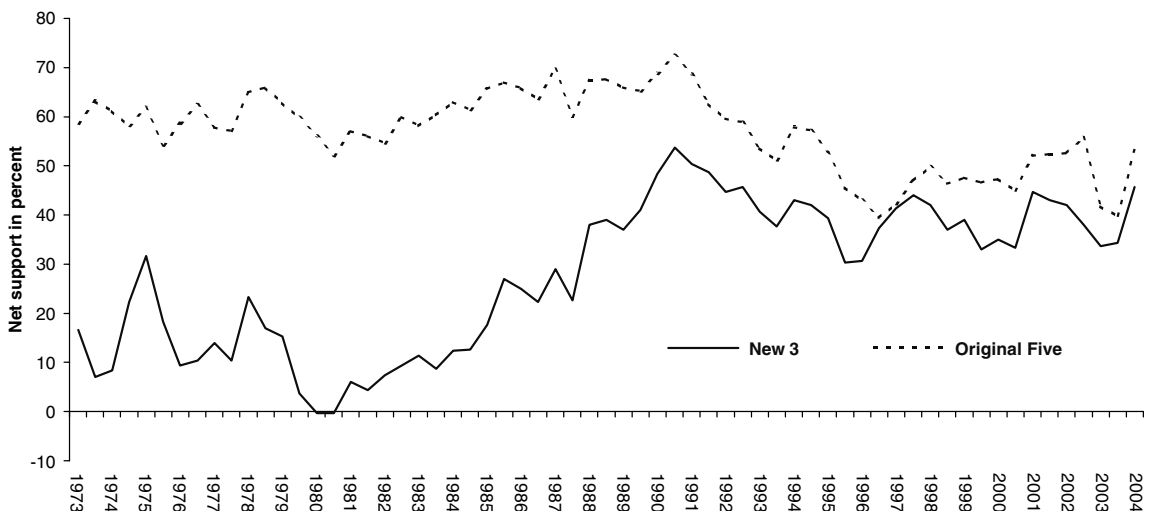

Figure 2 Evolution of net support among original five and three newer EU members, 1973-2004. Source: Eurobarometer surveys. Note: Luxembourg is not included among the original EEC members because of the small sample size of Eurobarometer surveys in that country.

coefficients for the UK and Denmark - traditional EU skeptics - are smaller than in comparable research, and the previous negative coefficient for Ireland is now positive. ${ }^{9}$ These findings imply that national traditions as well as economic effects are now less helpful in understanding cross-European variation in citizen support for integration.

One reason for the diminished influence of these predictors may be the crossnational convergence in support for integration (Figure 2). The figure compares the average level of support for integration within the original five members of the EEC (Belgium, France, Germany, Italy, and the Netherlands) to the average level of support within the three 1975 entrants (Denmark, Ireland, and the UK).

Until well into the 1980s, a substantial gap separated the original five and newer three members in their EU support - over 40 percentage points in 1973 and still as high as 30 points in 1988. During the 1980s, however, the gap began to close, especially between the signing of the Single European Act in 1985 and the signing of the Maastricht Treaty in 1991. Although support declined everywhere in the aftermath of Maastricht, the gap between the old and new members continued to narrow. Moreover, this convergence resulted not just from the increased support of the formerly skeptical newer members, but also from decline in support among older members. For example, Irish support for integration by 1995 had risen to the level found in Italy and Holland (the highest in the EU), and support in Denmark, while still rather low, became more like Germany or Belgium, where support has stagnated or declined. Indeed, support among the original five members remained below the 
pre-Maastricht levels even after increasing somewhat after 1997. Thus, while there is still a cleavage between the original members and the newer members, it is now much smaller. As a result, the cross-European variability of public support has declined. ${ }^{10}$

In addition, there has also been some convergence in export profiles within Europe. Export profiles show a narrowing gap in intra-EU trade concentration across the older and newer EU members. The narrowing gap is also largely (but not exclusively) a consequence of the increasing European orientation of the newer members: Irish, Danish, and English exports have become substantially more oriented toward Europe. As a result, the cross-European variability (standard deviation) of export profiles has declined almost monotonically. ${ }^{11}$

The coincidence of these two trends may explain why the statistical results are weaker when we analyze the most recent data. These EU members today are simply less differentiated in levels of support for integration, and variables that represent cross-national differences such as national traditions or export concentration are also converging and thus are not as useful in tracking crossnational variation in citizen support.

To evaluate these trends more precisely, we re-specified our regression model to explicitly capture cross-national convergence and the post-Maastricht effects. First, we changed the model to explicitly evaluate the convergence phenomenon observed above. Convergence is modeled by specifying the first difference in support for integration as a function of the lagged value in the level of support (Support $t_{t-1}$ ). This specification asks if the magnitude of the yearly change in support is higher or lower at different levels of support. Given the evidence of convergence noted above, we expect a significant negative coefficient on this variable (countries at low levels of support have shown larger positive gains in support). Second, we explicitly modeled the postMaastricht phenomenon by specifying period-specific 'controls' for the macroeconomic and trade effects. These variables take the value of zero prior to the signing of the Maastricht Treaty in 1991 and their actual values thereafter (post-Maastricht controls). The post-Maastricht controls isolate the impact of the trade and macroeconomic variables in the period after the Treaty.

Table 2 presents the results from these analyses. First, the parameter for the lagged level of support is negative and highly significant, strongly confirming the convergence pattern. Second, inflation, GDP, and intra-EU exports are strongly related to public support for integration in the expected directions, but only for the period through 1991. ${ }^{12}$ The post-Maastricht 'controls', in contrast, show that the impact of these variables evaporated in the aftermath of the Treaty: the signs prevalent in the prior period have reversed for most variables and none are statistically significant (post-Maastricht controls). 
In summary, when the post-Maastricht years are included in the analysis, support for integration is more difficult to model statistically, and the causal dynamic of previous periods is substantially altered. Through 1991, public opinion responded very much in the way that the existing literature would lead us to expect: support for integration responded positively to increased trade within the EU and to improvement in economic conditions. Since Maastricht, however, these relationships have essentially disappeared. The important question, of course, is why.

Table 2 Modeling convergence and post-Maastricht effects: revised regression estimates, 1974-2004

\begin{tabular}{|c|c|c|}
\hline Dependent variable $=$ change in net support $(N=496)$ & Parameter & Panel corrected standard error \\
\hline Constant & -0.2 .958 & 4.259 \\
\hline \multicolumn{3}{|l|}{ Net support $_{t-1}$} \\
\hline Macroeconomic performance, 1974-1991 & $-0.197 * * *$ & 0.032 \\
\hline$G D P$ & $10.745^{* *}$ & 4.777 \\
\hline Inflation & $-1.066 * * *$ & 0.349 \\
\hline Unemployment & -0.207 & 0.205 \\
\hline \multicolumn{3}{|l|}{ Trade concentration, 1974-1991 } \\
\hline Intra-EU export \% & $0.107 * *$ & 0.049 \\
\hline \multicolumn{3}{|l|}{ Post-Maastricht controls, 1992-2004 } \\
\hline GDP & -4.926 & 4.334 \\
\hline Inflation & -0.052 & 1.254 \\
\hline Unemployment & 0.179 & 0.256 \\
\hline Intra-EU export \% & -0.040 & 0.045 \\
\hline \multicolumn{3}{|l|}{ Political events } \\
\hline UK membership referendum & $18.806^{* * *}$ & 5.407 \\
\hline Danish SEA referendum & $21.037 * * *$ & 7.365 \\
\hline \multicolumn{3}{|l|}{ National traditions } \\
\hline UK & $-5.551 * * *$ & 1.574 \\
\hline Denmark & $-4.286^{* * *}$ & 1.388 \\
\hline Ireland & 1.154 & 1.319 \\
\hline Italy & $5.293 * * *$ & 1.235 \\
\hline Netherlands & $3.425 * * *$ & 0.947 \\
\hline$R^{2}$ & 0.169 & \\
\hline
\end{tabular}

$* * * P<0.001 ; * * P<0.01$.

Estimates follow the procedures described in Beck and Katz $(1995,1996)$ : ordinary-least squares estimates with panel-corrected standard errors and a nation-specific correction for serial autocorrelation. 


\section{Post-Maastricht Blues}

It is no secret that the signature and ratification of the Maastricht Treaty unleashed a period of political backlash against the European Union. The backlash began with the initial refusal of the Danes to ratify the Treaty and continued with the unexpected difficulties of ratification in France. As the Economist observed in 1997, 'Europe's people seem disillusioned with the whole Euro-business' (31 May 1997, 3).

Yet if the malaise was obvious, precisely what caused it remains unclear. To be sure, it is not so much that there are no explanations as that there are too many. Three principal hypotheses are frequently discussed:

\section{Too much too soon}

As we noted earlier, the Maastricht Treaty required Europeans to conceive of the integration process as more than merely an economic enterprise. Maastricht drastically transformed the Union's institutional basis by introducing European citizenship, increased majority voting in the Council, and expanded powers for the European Parliament. In addition, the Union extended its policy competence to include powers in the areas of environment, home affairs, social (and worker) policy, and foreign and security policy. The decline in citizen support during the 1990s might therefore signal a rejection of this dramatic acceleration in the scope and depth of the integration process. Moreover, the attenuation of the correlation between economic conditions and support for integration is a logical consequence of this evolution: since the Union has become far more than an economic enterprise, citizen evaluations of integration should be based on factors other than (or in addition to) economic performance. Empirically, this hypothesis would predict a generalized public rejection of the integration process.

\section{Foreign policy and the frustrations of disunity}

A second hypothesis is that the Union suffered from its widely publicized failure to arrive at common positions in external policy, beginning with the Persian Gulf War in early 1991 and continuing through the protracted period of debate and negotiation over Bosnia that ended with the Dayton Agreement in 1995 - precisely the period that encompasses the steepest decline in support for the EU (recall Figures 1 and 2). The aspiration to a common foreign policy is longstanding, of course, as is the rhetorical justification for a European voice in global affairs (Smith, 2003). However, during the early to mid-1990s, events in the Persian Gulf and the Balkans emphasized that it was precisely in the field of foreign policy that the aspiration to unity and global influence foundered on 
the diversity of national interests that member states bring to the enterprise. Empirically, if the post-Maastricht alienation were due to the frustrations arising from the EU's external impotence, we would expect attitudes toward defense and foreign policy integration to stand out from other policy attitudes. Specifically, support for integration in these fields should grow disproportionately during the early 1990s especially.

\section{EMU, the convergence criteria, and budgetary politics}

Finally, EMU may be the cause of citizen unease with the Union. Launched in the Maastricht Treaty in 1991, EMU had tremendous symbolic significance, leading to the replacement of national currency notes with the common Euro. Perhaps more important, the convergence criteria for the transition to EMU offer a plausible explanation for the attenuation of the relationship between economic factors and citizen support for the Union. Whereas citizens could formerly evaluate price stability as an undiluted positive in terms of its effect on personal standards of living, the control of inflation is now identified with its convergence siblings - particularly the control of budget deficits. As debates over budgets and social reforms in many countries illustrate, citizens became aware of what was always apparent to elites: that the transition to monetary union had budgetary as well as monetary consequences, and in Europe the importance of government spending programs to standards of living is significant. As a result, EMU is now debated as much for its impact on government spending as it is for its impact in the field of monetary policy. From the perspective of pensioners or recipients of health benefits (to name just two very large constituencies), little in this debate reflects positively on monetary union.

In summary, each of these post-Maastricht experiences might explain the recent decline in citizen evaluations of EU membership. Each of these explanations also helps understand why the correlation of economic conditions and citizen support has been attenuated. Unfortunately, truly historical data that would allow us to fully evaluate these competing explanations are simply not available for the time period encompassed by research on support for EU membership generally. However, a set of recent Eurobarometer questions allows an evaluation of factors that underlie citizen evaluations.

Since 1989, Eurobarometer has fielded a series of questions on what might be called support for 'policy integration':

Some people believe that certain areas of policy should be decided by the (NATIONAL) government, while other areas of policy should be decided jointly within the European Union.... Which of the following areas do you think should be decided by (NATIONAL) government, and which should 
be jointly decided within the European Union... [Security and Defence? ... Health and Social Security? ... Currencies?]...

This question has several analytic advantages. First, the question forces citizens to specifically consider the allocation of policy authority between the national and EU levels. Second, the questions elicit opinions in many issue areas (as many as 22), which allows for a comparison of preferences across issues areas. Finally, the questions have been included in the bi-annual Eurobarometer since 1989, which allows us to trace policy preferences over time.

Figure 3 shows the average level of citizen net support for the integration of specific policy domains over the 1989-2002 time period. ${ }^{13}$ Several features of the responses stand out. First, citizens make clear distinctions between policy areas that they believe should be governed at the EU level and those that should be retained within the national sphere of authority. For example, support for integrated EU authority in development cooperation policy, science and technology policy, foreign policy, and environmental policy outweighs opposition by as much as 30 to 50 percentage points, while the comparable figures for social security, worker rights, and education policy are precisely the opposite: opposition to integration outweighs support by as much as 30 percentage points. Moreover, the preference ordering shown in Figure 3 is quite stable. Despite ebbs and flows in support across all policy areas, the rank order of preferences remains very much the same from year to year (Dalton and Eichenberg, 1998; Gabel and Anderson, 2002; Hooghe, 2003). Europeans seem quite clear in the judgment that foreign policy (for example) should be conducted by the Union as a whole, but that education and social security policy most emphatically should not.

Second, Europeans also made differentiated judgments in the aftermath of the Maastricht reforms. Figure 4 shows that during the period of most drastic decline in support for EU integration generally (1991-1994), support for policy integration also declined in most issue areas, but it actually increased in some (immigration, foreign policy, security, and defense). Declines were relatively small in some areas (worker codetermination, education), but quite large in others (social security, currency, rules for radio and TV). Although the correspondence is not perfect, in general those policy areas that historically enjoyed public support as targets of integrative effort did not decline in the aftermath of Maastricht. In contrast, support did decline in those policy areas that Europeans traditionally 'reserved' for national authority. In summary, these data suggest that the Treaty of Maastricht evoked citizen concerns about the proper bounds of the integration process.

Most importantly, the data contradict the first two hypotheses discussed above. Were Europeans reacting generally to an integration process that was 'too much too soon', we would expect to find declining support for policy 


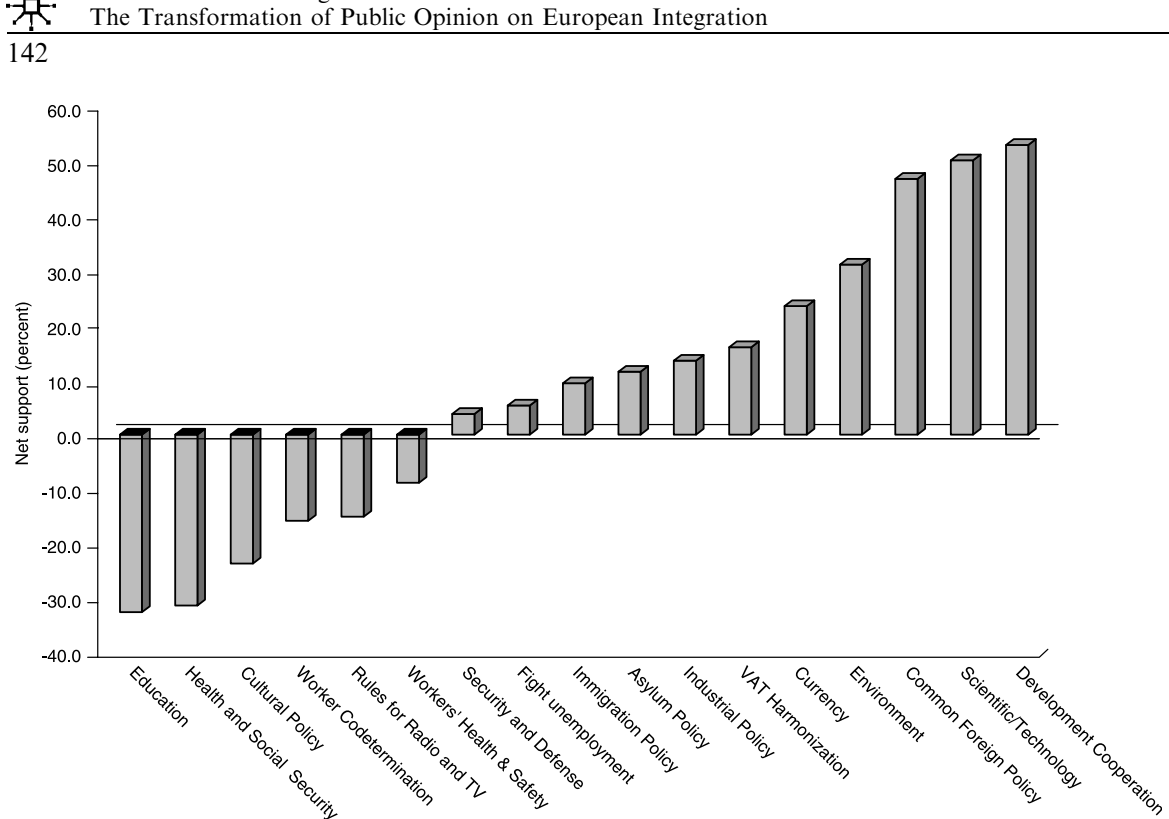

Figure 3 Average net support for integrated EU authority by policy area, 1989-2002.

integration in all policy areas. That is not the case. Citizens discriminated, with support declining steeply in some policy areas while increasing in others. Nor does the second hypothesis find much support. True, in the fields of foreign policy and defense, support did increase modestly, but the resulting support levels remain pretty much at their long-term average. Certainly there was not a drastic upsurge in support for defense policy integration.

The third hypothesis finds the strongest confirming evidence. As Figure 4 shows, during the period when support for EU membership declined the most (and was less correlated with economic conditions), it was accompanied by the steepest declines in support for the issues of 'currency' (EMU), policy areas with substantial budgetary implications (health and social security, harmonizing VAT, education), and areas dealing with the national culture (regulation of radio and $\mathrm{TV}$, education). Although the correspondence is not perfect, it is far closer than that of the other two hypotheses. This evidence suggests that citizens became sensitive in the post-Maastricht period to the intrusion of EU authority into areas that traditionally involved national (budgetary) policies for maintaining and distributing standards of living and policies that cultivate the national culture and identity.

The apparent concern for the impact of integration on popular spending programs is dramatically confirmed in a final analysis of these data. Figure 5 shows the cross-national relationship between the size of the welfare state and 


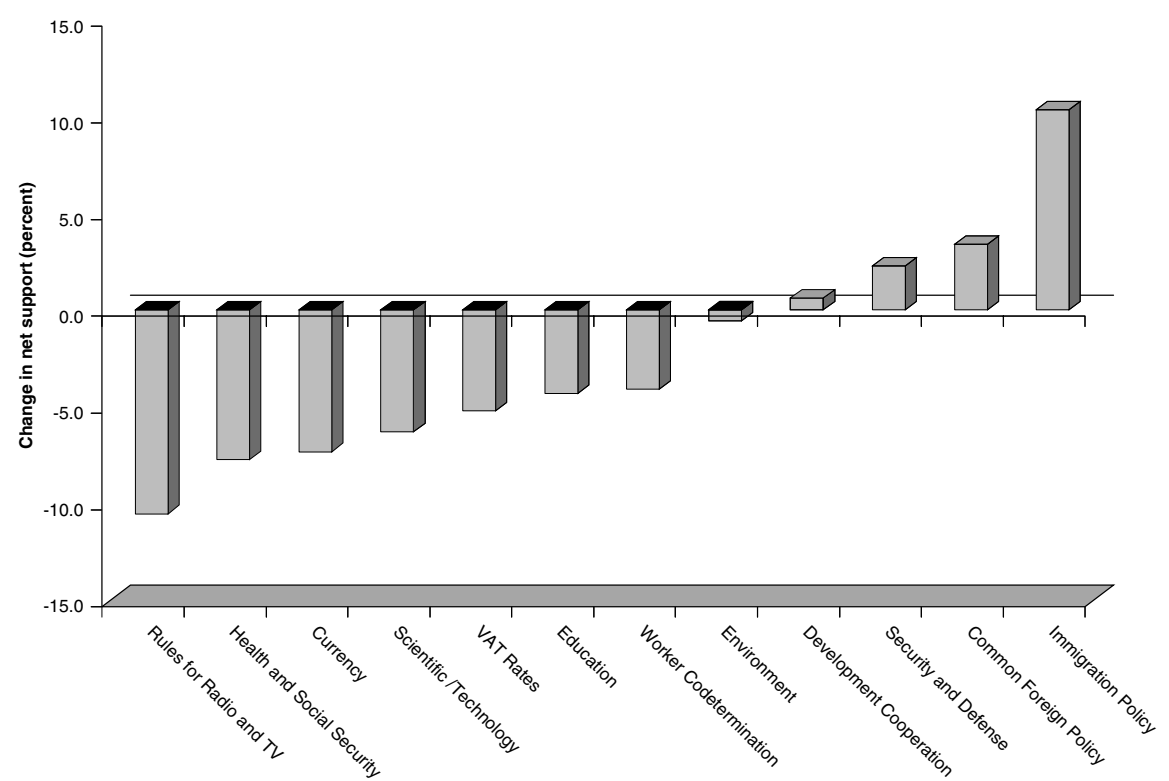

Figure 4 Change in net support for policy integration: 1991:I-1994:II.

the average level of support for integrating 'health and social security'. The relationship is steep, negative, and highly significant statistically: the larger the welfare state, the stronger the opposition to the intrusion of the EU into social security and health policy. ${ }^{14}$ Put differently: citizens in the largest welfare states are much more opposed to EU authority in this policy domain than citizens in states with smaller welfare programs. In addition, it was in the fields of health and social security that citizen support for policy integration reacted most negatively after Maastricht. The conclusion seems clear: Europeans want to protect social programs from EU harmonization, and Maastricht raised fears about these programs. After Maastricht, European integration represented much more than a macroeconomic enterprise. Integration became an issue of redistribution.

\section{Conclusions and Implications}

Our findings demonstrate that the transition to EMU changed the basis on which citizens evaluate the policy performance of the European Union. For the period prior to the Maastricht Treaty of 1991, the evidence here and in previous research showed that the Union's two major policy accomplishments 
the growth of intra-European trade and joint efforts to achieve price stability - were rewarded with favorable citizen reactions. In the postMaastricht era, these relationships no longer exist.

The contrast in the pre- and post-Maastricht periods indicates that as citizens became aware of the implications of EMU and the EU's changing policy role, their calculus of support changed. Our evidence suggests that citizens reacted to the immediate and direct consequences of EMU, as budget austerity in the transitional period raised immediate fears of cuts in government programs. Nonetheless, the evidence is also consistent with another possibility: that Europeans also feared the fulfilment of what appeared to them to be a neofunctionalist nightmare - gradual pressure in the wake of EMU to harmonize or even integrate popular social security and other spending programs, a possibility that was surely not assuaged by the prominence of the social charter in the Maastricht and Amsterdam Treaties. ${ }^{15}$ Attitudes toward 'policy integration' suggest that these are the policy areas that citizens wish to protect from Union control. And it was precisely in the areas of social security, health and worker safety, education, and culture, that there was

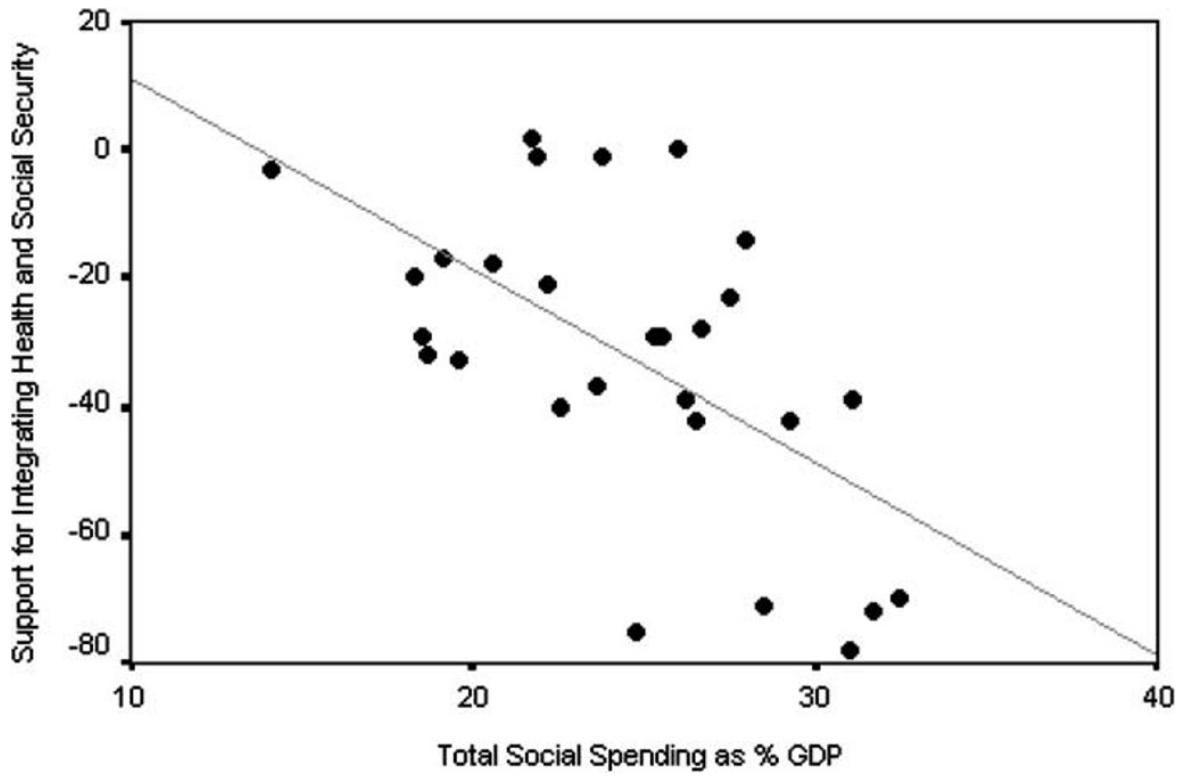

Figure 5 Relationship between total social spending and support for integrating health and social security. The unit of analysis in this graphic is the average level of support for integrating health and social security in two timeframes (1990-1996 and 1997-2002) for 14 EU members. The values on the $X$-axis are total social spending as a percentage of GDP in 1990 and 1995; the $Y$-axis is average support for EU action on health and social security. 
a negative reaction post-Maastricht. Support for harmonizing these policy areas was already low, and Maastricht drove it lower.

This suggests two obvious implications for the future of EU politics. First, the Union will face substantial citizen resistance if it moves to integrate social security and other policies with large budgetary implications. Second, budget cuts or policy reforms that appear to arise from the requirements of EMU are unlikely to escape a negative political reaction.

Our findings also help to explain what would otherwise represent a political anomaly: the fact that EU governments persisted with the implementation of EMU despite a truly drastic withdrawal of popular support. Yet their persistence seems understandable on the basis of our findings, for the public outcry appears to have stemmed from fears for the welfare state rather than from rejection of EMU per se. Indeed, as was suggested by McNamara's observation quoted in the introduction, EMU as monetary policy is probably something that is neither interesting nor comprehensible to citizens, but threats to welfare programs are both.

To the extent that politicians feared public retribution, the politically safe strategy was to implement EMU without disturbing social spending programs in any major way. Although the final story of the welfare state in the 1990s has yet to be written, the evidence that does exist suggests that in fact governments did avoid major cuts in the most popular social programs. Indeed, data from official sources and several scholarly studies show that the largest components of the welfare state continued to grow. With very few exceptions, total social spending in real terms increased in most countries throughout the 1990s, and transfer payments to individuals also increased as a share of GDP in most states. ${ }^{16}$ When expenditure cuts were made, they fell not on transfer payments but on spending for the more general provision of public services (government consumption expenditure). As Clayton and Pontusson observe, this type of spending is popular as well, but for several reasons - including the greater visibility and legitimacy of transfer spending - it is probably less risky to cut general government spending than to cut individual entitlements to transfers. ${ }^{17}$ In summary, although governments did restrain and even cut some spending during the transition to EMU, in so doing they protected the largest and most politically popular transfer programs.

At least during the 1990s, then, governments could implement EMU without attacking the most popular social spending programs. However, European politicians may not be able to maintain this delicate balancing act for very much longer. In the first place, the upward pressure on entitlement programs will continue as populations age. In addition, the commitment to the European Policy on Security and Defence (EPSD) and a European rapid deployment force will create political pressure for at least modest increases in defense spending. Finally, the ECB has made price stability its highest priority, and it 
surely will be watchful for fiscal policies that it considers an inflationary threat. For the foreseeable future, then, the obligation to maintain budgetary stability under EMU will maintain pressure on governments to restrain and perhaps even cut spending. Our findings indicate that the Union's policy legitimacy will therefore remain precarious, and as we suggested above, the public seems clear in its message that 'reform' of social programs remain in national hands.

The evidence therefore suggests the need to reconsider models of citizen support for European integration in a way that supplements the macro political economy perspective that has dominated the literature. To be sure, it would be unwise to completely ignore macroeconomic performance as a basis of citizen consensus (Netjes, 2004), but it also seems clear that citizens are increasingly concerned that the integration process now affects their livelihoods more directly than has been the case in the past. As a result, models of support must now take account of the more specific policy preferences of European citizens and the political coalitions that surround the welfare state in particular (Sinnott, 1995; Dalton and Eichenberg, 1998). The politics of integration are no longer the politics of absolute welfare; they are the politics of redistribution.

There is irony in this development. In what is certainly the most astute study of opinions at the individual level, Gabel (1998a)showed that citizens in fact evaluate the EU on the basis of their personal 'comparative advantage', that is, on the basis of their ability to take advantage of the gains from increasing intra-European trade. In addition, people respond to variations in the benefits of integrative policies, such as regional funds and the Common Agricultural Policy (CAP) (Whitten et al., 1996; Netjes, 2004). Gabel thus observes that there is a potential basis for a transnational cleavage structure that might replace the inherited class and partisan basis of national politics, but also that substantial transnational association structures have yet to emerge. One reason, he argues, is that policy aggregation and implementation still occur largely at the national level (Gabel, 1998a, 117-119).

This is nowhere more true than in the area of social policy - pensions, health insurance, family policy, education - that most directly impinges on individual standards of living. In fact, these policy areas are far more than technical instruments for dealing with societal problems. They represent the fundaments of the post war political economic consensus that replaced the divisions and hostilities of the pre-war period. As a result, they are deeply rooted in inherited national cleavage structures, and when - or if - the EU attempts to harmonize these policies, it is these cleavage structures that will be evoked. ${ }^{18}$ Thus, it is becoming increasingly apparent that the study of European integration must combine the political economy models derived from international and comparative political theory with the distributional and 
historical models developed in the fields of comparative politics and comparative political sociology. ${ }^{19}$ Perhaps more than any other research problem, the study of European integration will require the dissolution of the boundaries between international and comparative political inquiry. ${ }^{20}$

This seems all the more important given a second prominent finding reported above: the fact that there has also been a post-Maastricht decline in support for the integration of 'cultural' policies, such as education or regulation of telecommunications. There is also now substantial cumulating evidence that national identity is an important determinant of support for integration (Marks and Hooghe, 2003; Hooghe and Marks, 2004, 2005; Netjes, 2004; McLaren, 2002). Just as the national welfare state is the material core of the post war consensus, it appears that a commitment to national identity and culture remain a core commitment of European citizens even as they support the broad tenets of market integration. Given the increasing popular connection in Europe between 'globalization' and threats to national cultures, it would be surprising to find the European Union moving in any major way toward an integrated cultural regime. What is more, given the sensitivity of public opinion to cultural issues, it would not be surprising to find the Union acting as the protector of European cultures and identities from the real or perceived forces of globalization emanating from outside of Europe. The paradox, of course, is that the Union is protecting identities that are national rather than European.

\section{References}

Anderson, J. (1995) 'The state of the (European) union: from the single market to Maastricht, from singular events to general theories', World Politics 47: 441-465.

Anderson, C.J. and Kaltenthaler, K. (1996) 'The dynamics of public opinion toward European integration, 1973-1993', European Journal of International Relations 2: 175-199.

Anderson, C.J. and Reichert, M.S. (1995) 'Economic benefits and support for membership in the EU', Journal of Public Policy 15: 231-249.

Beck, N. and Katz, J. (1995) 'What to do (and not to do) with time-series-cross-section data', American Political Science Review 89: 634-647.

Beck, N. and Katz, J. (1996) 'Nuisance versus substance: specifying and estimating time-seriescross-section models', Political Analysis 6: 1-36.

Bednar, J., Ferejohn, J. and Garrett, G. (1996) 'The politics of European federalism', International Review of Law and Economics 16: 279-294.

Cameron, D. (1978) 'The expansion of the public sector: a comparative analysis', American Political Science Review 72: 1243-1261.

Clayton, R. and Pontusson, J. (1998) 'Welfare-state retrenchment revisited: entitlement cuts, public sector restructuring, and inegalitarian trends in advanced capitalist societies', World Politics 51: $67-98$.

Dalton, R.J. and Eichenberg, R.C. (1993) 'Citizen Support for Policy Integration', in W. Sandholz and A.S. Sweet (eds.) Supranational Governance: The Institutionalization of the European Union, New York: Oxford University Press. 
Eichenberg, R.C. and Dalton, R.J. (1993) 'Europeans and the European Union: the dynamics of public support for European integration', International Organization 47: 507-534.

Eichenberg, R.C. and Dalton, R.J. (2003) 'Theory matters: cumulation in the study of citizen support for European integration', Unpublished manuscript.

Esping-Andersen, G. (1990) The Three Worlds of Welfare Capitalism, Princeton: Princeton University Press.

European Council (1996) 'Presidency Conclusions, Turin, 29 March.

Flora, P. and Heidenheimer, A. (eds.) (1982) The Development of Welfare States in Europe and America, New Brunswick, NJ: Transaction Press.

Franklin, M.N. and Wlezien, C. (1997) 'The responsive public: issue salience, policy change, and preferences for European Unification', Journal of Theoretical Politics 9: $347-363$.

Frieden, J. (1994) 'Making Commitments: France and Italy in the European Monetary System, 1979-1985', in B. Eichengreen and J. Frieden (eds.) The Political Economy of European Monetary Integration, Boulder, CO: Westview Press.

Frieden, J. (1998) 'The Euro: who wins? Who loses?', Foreign Policy no.114 (September): 25-40.

Gabel, M. (1994) 'Divided Opinion, Common Currency: The Political Economy of Public Support for EMU', in B. Eichengreen and J. Frieden (eds.) The Political Economy of European Monetary Integration, Boulder, CO: Westview Press.

Gabel, M. (1998a) Interests and Integration: Market Liberalization, Public Opinion, and European Union, Ann Arbor: University of Michigan Press.

Gabel, M. (1998b) 'Economic integration and mass politics: market liberalization and public attitudes in the European Union', American Journal of Political Science 42: 936-953.

Gabel, M. and Anderson, C. (2002) 'The structure of citizen attitudes and the European Political space', Comparative Political Studies 35: 893-913.

Gabel, M. and Palmer, H. (1995) 'Understanding variation in public support for European integration', European Journal of Political Research 27: 3-19.

Gabel, M. and Whitten, G. (1997) 'Economic conditions, economic perceptions, and public support for European integration', Political Behavior 19: 81-96.

Garrett, G. (1998) Partisan Politics in the Global Economy, New York: Cambridge University Press.

Garrett, G. and Mitchell, D. (1999) 'Globalization and the welfare state, Department of Political Science, Yale University, Working Paper.

Hooghe, L. (2003) 'Europe divided? Elites vs public opinion on European integration', European Union Politics 4: 281-304.

Hooghe, L. and Marks, G. (1997) 'Comparative politics and international relations: suggestions for a unitary approach', European Community Studies Association Review 10: 1-2.

Hooghe, L. and Marks, G. (1998) 'The Making of a Polity: The Struggle over European Integration', in H. Kitschelt, P. Lange, G. Marks and J. Stephens (eds.) Continuity and Change in Contemporary Capitalism, New York: Cambridge University Press.

Hooghe, L. and Marks, G. (2004) 'Does identity or economic rationality drive public opinion on European integration?', PS: Political Science and Politics 37: 415-442.

Hooghe, L. and Marks, G. (2005) 'Calculation, community, and cues: public opinion on European integration', European Union Politics 6: 421-445.

Iverson, T. and Cusack, T. (2000) 'The causes of welfare state expansion: deindustrialization or globalization?', World Politics 52: 313-349.

King, G. (1986) 'How not to lie with statistics: avoiding common mistakes in quantitative political science', American Journal of Political Science 30: 666-687.

Marks, G. and Hooghe, L. (2003) 'National identity and European integration', Department of Political Science, University of North Carolina, March 2003, Working Paper. 
McLaren, L. (2002) 'Public support for European integration: cost/benefit analysis or perceived cultural threat?' The Journal of Politics 64: 551-566.

McNamara, K. (1998) The Currency of Ideas: Monetary Politics in the European Union, Ithaca, NY: Cornell University Press.

Moravcsik, A. (1998) The Choice for Europe: Social Purpose and State Power from Messina to Maastricht, Ithaca, NY: Cornell University Press.

Nelson, B.F. and Guth, J. (2000) 'Exploring the gender gap: women, men, and public attitudes toward European integration', European Union Politics 1: 267-291.

Netjes, C. (2004) 'All Aboard? Explaining Public Support for European Integration in a PostMaastricht Era', Paper prepared for the panel 'Public Opinion and EU Enlargement' at the 2nd Pan-European Conference, Bologna, Italy, 24-26 June.

OECD [Organization for Economic Cooperation and Development] (2002) National account statistics of OECD member countries, Volume II, Detailed Tables, Paris: Organization for Economic Cooperation and Development.

Pierson, P. (1996) 'The new politics of the welfare state', World Politics 48: 143-179.

Pierson, P. and Leibfried, S. (1995) 'Semisovereign Welfare States: Social Policy in a Multitiered Europe', in Leibfried S. and Pierson P. (eds.) European Social Policy: Between Fragmentation and Integration, Washington: The Brookings Institution.

Pryce, R. (1973) The Politics of the European Community, Totowa, NJ: Rowman and Littlefield.

Sinnott, R. (1995) 'Policy, Subsidiarity, and Legitimacy', in O. Niedermayer and R. Sinnott (eds.) Public Opinion and Internationalized Governance, New York: Oxford University Press.

Smith, M. (2003) Europe's Foreign and Security Policy: The Institutionalization of Cooperation, Cambridge: Cambridge University Press.

Whitten, G., Gabel, M. and Palmer, H.D. (1996) 'Euro-pork: How EU Fiscal Policy Influences Public Support for Integration', Paper presented at the Convention of the International Studies Association, San Diego.

\section{Notes}

1 We are grateful to Thomas Cusack and Matthew Gabel for thoughtful suggestions on this manuscript. We also acknowledge with gratitude the comments and assistance of Geoffrey Garrett, Carlos Granier, Anke Grosskopf, Kathleen McNamara, Alberta Sbragia, Judith Walcott, and participants in a seminar of the Center for West European Studies, University of Pittsburgh.

2 This hypothesis was hardly revolutionary. Roy Pryce (1973) quite early argued that popular support for integration lay in rationalist calculations, especially "the expectation of benefits to be derived from union... the formation of the customs union has given more and more individuals and groups a stake in the Community: they see it as necessary in terms of their own welfare.... In short, the Community is now widely regarded as an essential instrument for the maintenance of a prosperous economy and a necessary precondition for a rising standard of living.' Pryce (1973, 32-33).

3 Another excellent account is provided by McNamara (1998, 131-158). She agrees with Moravcsik that the shift to austerity and price stability was linked to participation in the EMS, although McNamara does not emphasize the use of European harmonizationas a political strategy to justify domestic policies.

4 For a thorough elaboration of the domestic distribution of the costs and benefits of monetary policy coordination and integration, see Frieden (1994, 1998).

5 Economic growth in the first half of the 1990s (1.07\% real) was the third best half-decade since 1973. Inflation in the first half of the 1990s reached the lowest levels recorded since 1973 
(an average of less than $1 \%$ on a quarterly basis). Intra-EU export concentration grew from an average of $62 \%$ in the late 1980 s to $65 \%$ through the $1990 \mathrm{~s}$. Although there was a harsh recession and a major increase in unemployment in 1991, support for integration did not rebound after recovery began, which is what past research would predict.

6 The countries are Belgium, Denmark, France, Germany, Ireland, Italy, the Netherlands, and Great Britain. In separate analyses, we established the robustness of our findings for all countries that were EU members since 1985 (thus adding Greece, Spain, and Portugal). In earlier analyses, we also compared the alternative estimation techniques suggested by Beck and Katz (1995, 1996) for pooled cross-section time-series models (CSTS). The results were robust across all estimation techniques. These broader results are discussed in Eichenberg and Dalton (2003). Note also that the final estimates presented below employ the most conservative technique for CSTS data: direct modeling of dynamics (lagged dependent variable) and panel corrected standard errors. The estimates were computed using the 'XTPCSE' command in Stata 7.0.

The updating of earlier data series also does not appear to be a confounding factor. We followed the definitions and sources described in Eichenberg and Dalton (1993), and the updated series correlate quite highly with the original series in both the pooled sample and within individual countries (well over 0.90).

7 We also considered whether the omission of indifferent respondents ('neither good nor bad') biases the measure of net support? If net support is computed more conservatively ('good thing' minus the sum of 'bad thing...neither good nor bad'), it correlates at 0.99 with the initial measure in the pooled sample and never less than 0.96 within countries.

8 Appendix I contains definitions and data sources for these variables.

9 The direct comparison is to Dalton and Eichenberg (1993, 522), but see also fixed effect coefficients in Gabel and Palmer (1995) and Bednar et al. (1996).

10 The pooled standard deviation of net support is as follows: 1973-1975 (24.4); 1976-1980 (28.0); 1981-1985 (27.4); 1986-1990 (21.9); 1991-1995 (17.8); 1996-2000 (22.1); 2001-2004 (18.9).

11 The standard deviation of intra-European exports is as follows: 1973-1975 (14.6); 1976-1980 (13.1) 1981-1985 (11.5); 1986-1990 (10.6); 1991-1995 (9.1); and 1996-2000 (8.4); 2001-2004 (10.3).

12 By specifying lagged support to model the dynamics of cross-national convergence, we presumably attenuate other variables-such as exports — which differentiate cross-national levels of support but which are already captured in the lagged level of support. Nonetheless, the preferable approach on methodological grounds is to model the dynamics directly. See Garrett (1998) and Beck and Katz (1996).

13 Net support is calculated by subtracting those who prefer 'national' policy authority from those who prefer EU policy authority.

14 This strong negative correlation is not an artifact of a generalized negative relationship between the size of the welfare state and support for policy integration in all policy areas. Support in many policy areas is entirely uncorrelated with the size of the welfare state. Only support for integrating social security/health and 'worker codetermination' are negatively correlated and significant at the 0.001 level. At the 0.05 level, the negative correlation is significant only for integrating worker health and safety, cultural policy, and development assistance. With the exception of development assistance, all of these areas deal with social spending, the social contract more generally (worker rights), and the definition of cultural values.

15 That such pressure might indeed exist despite the hesitancy of European governments to integrate social policies is suggested in Pierson and Leibfried (1995, 72-74).

16 Garrett and Mitchell (1999), Iverson and Cusack (2000), and OECD (2002).

17 Clayton and Pontusson (1998).

18 One intriguing example is the speculation by Clayton and Pontusson (1998) that the strength of political support for cash transfer spending results from a coalition of workers and owners in the 
export sector. In this view, continuing support of both labor and capital for cash transfer programs represents a political bargain to gain the support of workers for policies of economic openness. Note that this argument conforms to the finding that the size of the public sector is strongly correlated with the degree of exposure to the world economy (Cameron, 1978). Iverson and Cusack (2000) and Garrett and Mitchell (1999) provide updates to Cameron's analysis, and Hooghe (2003) shows on the basis of the 'policy integration' opinion series that Europeans generally favor 'market flanking' policies designed to protect workers from the effects of liberalization.

19 Some important works in a huge literature include: Flora and Arnold Heidenheimer (1982), Esping-Andersen (1990), Pierson (1996), Pierson and Leibfried (1995), Clayton and Pontusson (1998), Garrett and Mitchell (1999), and Iverson and Cusack (2000).

20 On these points, see J. Anderson (1995) and Hooghe and Marks (1997, 1998).

\section{Appendix I}

\section{Data and Sources}

Net Support is the difference between the percentage of survey respondents who feel that their country's membership in the Union is a 'good thing' minus the percentage who feel it is a 'bad thing'. Source: Commission of the European Communities, Eurobarometer (Brussels, bi-annual) and the 1973 European Communities Study.

Inflation is the quarterly percentage change in the Consumer Price Index (all items). We employ second and fourth quarter percentage change to match the timing of the Eurobarometer surveys. Source: OECD, Main Economic Indicators: Historical Statistics, (Paris, various years) and Main Economic Indicators (Paris, monthly).

Unemployment is the seasonally adjusted quarterly percentage of the total labor force that is unemployed ('standardized unemployment rate'). We use second and fourth quarter figures to match the timing of the Eurobarometer surveys. Because of a change in reporting unemployment figures for Ireland, annual data are used for that country. Source: see Inflation, and for Ireland, European Economy, 62 (1996), p. 58 and later years.

GDPindex is an annual index of real Gross Domestic Product $(1990=1.00)$ computed from national currencies. Source: OECD (Organization for Economic Cooperation and Development), National Account Statistics of OECD Member Countries, 1966-1994, Volume I, Main Aggregates (Paris, 1996), and Main Economic Indicators (Paris, monthly).

EU Export \% is the ratio of a country's intra-EC exports to its total exports, measured in European Currency Units. Source: Commission of the European Communities, Statistical Yearbook of External Trade, (Brussels, various years); Monthly Statistics on External Trade, January-April, 1990; Basic Statistics of 
the Union (Brussels, yearly); and International Monetary Fund, Direction of Trade Statistics (Washington: yearly).

UK Referendum is a dummy variable for Britain only for the 1975 referendum election (UK, $1975=1$ ).

Danish referendum $S E A$ is a dummy variable for Denmark for the time point following the 1986 SEA referendum in Denmark (Eurobarometer 25). 